\title{
The reflection of Slovak politics in 1940 in Nicolae Lahovary's diplomatic reports
}

\author{
RADU FLORIAN BRUJA
}

\section{Ştefan cel Mare University, Suceava, Romania}

\begin{abstract}
In the study we present and interpret the activities of the Romanian diplomat Nicolae Eric Lahovary, who served as an ambassador to the Slovak Republic from March 1940 to March 1941. Although he was ambassador until March 1941, we focus only at his perception of the internal and foreign policy of the Slovak Republic, as well as the form of mutual relations between Slovakia and Romania until September 1940. This perception is based mainly on his diplomatic reports that have been sent regularly to the Ministry of Foreign Affairs of the Kingdom of Romania.

Keywords: Nicolae Eric Lahovary, Foreign Policy, Diplomacy, Kingdom of Romania, Slovak Republic, 1940.
\end{abstract}

DOI: https://doi.org/10.24040/ahn.2021.24.01.96-113

\section{Introduction}

Diplomatic relations between Romania and the Slovak Republic were established in a complex political conjuncture. The collapse of Czechoslovakia affected the security system of Great Romania. The new political formation that appeared on the map of Europe after the fall of the Czechoslovak federation was not taken up by the Romanian authorities. Due to the evident orientation of Bratislava towards the Reich and the diplomatic balance of Bucharest (which still hopes to save its integrity with the help of England and France), the beginning of diplomatic relations between the two countries was rather hesitant. Romania recognized Slovakia only in mid-June 1939, after three months of the existence of the small Danubian state. After another three months, the diplomatic missions in the capitals of the two countries were opened. Officially, diplomatic relations existed since September 1939, each country opening its Legation. Ivan Milecz was appointed envoy extraordinary and plenipotentiary of the Slovak Republic to Bucharest. If the diplomatic representative of Slovakia retained his post until August 1944, the changes in Romania's foreign policy imposed the change of accredited diplomats in Bratislava. From September 1939 to March 1940, Constantin (Dinu) Hiott led the Romanian Legation in the capital of Slovakia. From March 1940 to March 1941, the position was occupied by Nicolae Eric Lahovary. 
The reflection of Slovak politics in 1940 in Nicolae Lahovary's ...

As for Gheorghe Elefterescu's mandate, it was the longest, covering even the stage of political-diplomatic turning of Romania in August 1944. ${ }^{1}$

Thus, in 1939 and 1940, the Romanian-Slovak relations were influenced by the foreign policy orientation of the two countries. While Slovakia entered the sphere of influence of the Nazi Reich, which restricted its freedom of movement in the arena of international relations, Romania has sided with the Western Powers, pursuing a possible approach to Berlin for pragmatic reasons. The collapse of the Anglo-French political construction in June 1940 confronted both countries with a different situation. The summer of 1940 marked a change in the political orientation of Bucharest, influencing the Romanian-Slovak relations, which had been till then dominated by reticence. This study aims to analyse some aspects of the nature of the Romanian-Slovak relations during 1940. What was the international status of the small Central European republic and how was reflected its dependence on Germany? What foreign policy objectives did Slovakia pursue, and did they arouse the interest of Romania? What role did Hungary play in the Romanian-Slovak approach? How the political scene in Bratislava was perceived by Romania, and how the bilateral relations were influenced by the turmoil in Slovakia's domestic political life? We try to answer these questions using diplomatic reports issued by the Romanian Legation in Bratislava, in one of the most delicate moments in the history of the two countries.

The Romanian historiography neglected the subject of the Romanian-Slovak relations, some studies touching only partially on this issue. In Slovak historiography, Jana Bauerová based her research on documents from the central Slovak archive, exploring in various forms the relations between the two countries. Yet, the Slovak scholar did not have access to the Romanian sources such as the diplomatic reports written by Lahovary.

This analysis brings into attention some aspects of the first stage in Nicolae Lahovary's diplomatic activity in Bratislava, from April to September 1940. This interval overlaps the radical change in political orientation of the Slovak leaders after their meeting with Adolf Hitler, in Salzburg in July 1940. As for Romania, this moment coincides with the shattering of the 1918 Dream and the reorientation of the foreign policy towards Nazi Germany. Following the geopolitical adjustments in Europe, in the autumn of 1940 , Romania and Slovakia found themselves on the same side of the barricade, offering new directions for their diplomatic relations.

${ }^{1}$ The Institutional Organization of Ministry of External Affaires. Acts and Documents, vol. II (1920-1947). Ed. by Ion Mamina, George I. Potra, Gheorghe Neacşu, Nicolae Nicolescu. Bucharest : Titulescu European Foundation, 2006, p. 545. 


\section{The debut of Lahovary's diplomatic work in Bratislava.}

\section{First impressions}

In the context of German domination in the central and south-eastern parts of Europe, Romania tried to open new tracks to probe Berlin's intentions. At the same time, the revisionist agitation of Hungary compelled the Romanian diplomacy to seek new allies. These realities forced Constantin Hiott, known for his sympathy with former Czechoslovakia, to change. The Romanian government decided to replace him with a personality less close to Prague, who could guarantee a balance between Berlin and Paris. After talks with Grigore Gafencu and Alexandru Cretzianu, in January 1940, Ivan Milecz announced in Bratislava that Hiott would be changed. ${ }^{2}$ The agreement for the new minister was requested through the Slovak diplomat. On February $12^{\text {th }}$, Milecz announced that the secretary of the Romanian Legation in Vienna, Nicolae Lahovary, was to be nominated as a new minister in Bratislava, and that he had good references for this post. On February $20^{\text {th }}$, they made the official announcement. ${ }^{3}$ Thus, from March $1^{\text {st }} 1940$, Nicolae Enric Lahovary, former head of the Romanian Legation in Tirana between 1936 and 1939, and secretary of the Romanian Legation in Vienna between 1939-1940, was nominated to take over the leadership of the diplomatic mission of Romania in Bratislava.

The Slovak press has broadly published the reception of Lahovary in Bratislava by Radúz Radlinský, the head of the Protocol. He introduced him to Ferdinand Ďurčanský, the Minister of Foreign Affairs, with whom he spent an hour. The head of Slovak diplomacy came across to Lahovary as a "41-year-old-something man who reminds me of our MPs representing the constituencies of Banat in the House of Commons, and was until recently a lecturer at the Faculty of Law in Bratislava". The Romanian diplomat appreciated that "he did receive me most cordially, being clearly pleased that Romania had sent a minister here". Their discussion reached general themes without bilateral tightening arrangements. The diplomatic discretion and the vigilance of Berlin prevented the Slovak Minister from proposing more. But Lahovary understood that Slovaks' fear and dislike of the Hungarians were very great. Slovakia was too weak to oppose Hungary. He concluded that the Slovaks could not rely on Italy, which was too favourable to the Hungarian cause. He also added that although the Nazi Germany "is not too beloved in the bottom of souls”, until "the return of more normal times", the Reich is the "essential pledge of Slovak existence". It was obvious to the Romanian minister that Slovakia

\footnotetext{
2 Ministry of the Interior of the Slovak Republic, Slovak National Archive, Bratislava. Fund: Ministerstvo zahraničných vecí, 1939-1945, carton no. 194, document no. 1051.

3 Ibid, no. 1477.
} 
The reflection of Slovak politics in 1940 in Nicolae Lahovary's ...

wanted to get closer to Romania, but the circumstances did not allow it. In his first report, the Romanian minister also considered that Slovakia's relations with the Soviet Union were not bad, and Hungary could not do anything because of Germany. ${ }^{4}$

The reception of head of the state followed very soon. The audience with Monsignor Jozef Tiso took place in the Romanian and Slovak languages, avoiding the use of German, touching as the main theme the Hungarian problem. ${ }^{5}$ Lahovary said that the Romanian and Slovak peoples have a similar fate, and that it is time to establish closer ties between the two. Tiso exclaimed that "the friendship of our peoples has always been sincere and unequivocal. I am utterly convinced that the harsh fate our peoples had to face in the past is the guarantee of the best collaboration, so that no foreign rule will ever be reinstated." 6 Being known for his adversity towards Hungary, Tiso did not hesitate to declare that the Slovaks were willing to fight "to death" if attacked by the Hungarians "than to fall under the Hungarian yoke". What seems interesting is Tiso's confession that the Slovaks were afraid of their fate and depended on Germany's victory in the war. But under other conditions, they were thinking of alternatives, even in collaboration with U.R.S.S. against Hungary ${ }^{7}$. Lahovary noted that there is a sense of sympathy between the Slovak authorities and the Soviet minister in Bratislava, in many of these discussions pointing out "the Slavic character of the Slovak people and its affinities with the Russian people". 8 This could be a reaction to German domination and, at the same time, to the expansionist tendencies of the Hungarians. The press has extensively reported on Lahovary's visits to Tiso and Duurčanský. Articles in the official regime newspaper "Slovák”, accompanied by pictures, were pointing out the importance of this appointment. ${ }^{9}$

On April 18 1940 Lahovary had a meeting with Vojtech Tuka, the president of the Council of Ministers. The Romanian diplomat saw in him the only representative of the upper Slovak intelligentsia, mentioning that Tiso or the President of Parliament had modest origins. Lahovary believes that Tuka's view of the future of Central Europe was reasonable.

\footnotetext{
${ }^{4}$ Archives of the Ministry of the Foreign Affairs, Bucharest, fund 71 Slovakia, vol. 11, f. 102 103 (infra: A.M.F.A.).

${ }^{5}$ Ibid., Fund 71 Slovakia, vol. 11, f. 112-113; from another document we find out that only at the moment of handing the letter of accreditation, Lahovary was asked to use the Romanian language, and President Tiso answered in Slovak, the rest of the discussion being in German, p. 114.

${ }^{6}$ BAUEROVÁ, Jana: Slovensko a Rumunsko v rokoch 1939-1944. Trnava : Filozofická fakulta Trnavskej univerzity, 2014, p. 38.

${ }^{7}$ A.M.F.A. Bucharest, fund 71 Slovakia, vol. 11, f. 112-113.

${ }^{8}$ Ibid., f. 134.

${ }^{9}$ Ibid., f. 117-122.
} 
From the discussion with the Slovak leader, Lahovary noted that he believed that Germany could not be defeated. The Slovak Prime Minister had visited the Siegfried Line and considered it impenetrable. But Tuka expressed to the Romanian minister the opinion that Italy could be the key to German victory. Lahovary was surprised by the Slovak politician's view that Italy should play a more important role in the current war: "If Italy ends up taking arms alongside Germany, because it has more to gain from a German victory, the war will end with a compromise favourable to the Reich." Tuka hoped that England should think of a compromise solution to reconcile both camps. If the war prolonged, there was, in Tuka's opinion at that time, the danger of the expansion of the Bolshevism that would represent the "greatest catastrophe for Europe". But, in conclusion, the Slovak leader believed that at that moment there was no danger to Romania or Slovakia, but that at the end of the war it will be not possible for the two to find themselves in a federation of small states. ${ }^{10}$

A few days later, Lahovary had a meeting with Reich diplomat, Hans Bernard, who assured him that Germany was not seeing a possible Soviet aggression against Romania. He spoke of Molotov's speech as „an unpleasant surprise for Berlin", and he was of the opinion that "at least for the near future, Russia will not take any action against Romania". ${ }^{11}$ After having had meetings with other members of the Diplomatic Corps, he sent to Bucharest, on April 22 nd 1940, a report by which he made the first conclusions after the meetings he had had at the beginning of his mission in Slovakia. The Romanian minister believed that the German successes in Denmark and Norway secured a comfortable victory for Berlin and that it was a compromise solution for a return to a general peace. He also considered that Germany and Italy had enough military assets to prevent the war from widening in the south-eastern parts of the continent. He suggested that the Foreign Ministry should be cautious because it believed that Germany was not going to change the political situation in the region but could do so „with all its means through a massive and flashing action" if another power would threaten the interests in this space. He also warned that Hungary would let the German army transit it. Lahovary had information about the presence of numerous German divisions on the border between the former Austria and Hungary, which could be complemented by those in the Polish territory for a possible military action against Romania. He also expected Italy's political-diplomatic intervention in favour of Germany and even an attack in the Balkans if the situation was to be demanded. He was also convinced that the threat

\footnotetext{
${ }^{10}$ Ibid., vol. 1, f. 105-106.

${ }^{11}$ LUNGU, Corneliu Mihail - NEGREANU Ioana Alexandra: Romania in the Game of Great Powers 1939-1940. Bucharest : Curtea Veche Publishing House, 2003, doc. 57, pp. 258-259.
} 
The reflection of Slovak politics in 1940 in Nicolae Lahovary's ...

from U.R.S.S. would take "precise forms" under these conditions. That is why he believed that Romania should not be involved in the war on the Anglo-French side. The Romanian diplomat had learned these from German sources and warned that Soviet military action in Bessarabia could not be avoided. But it was advised that Germany did not want it and that the German-Romanian friendship was in the interest of both. He also notes the optimism of the dominant circles in Slovakia that the situation in the Danube basin will remain quiet. The conclusions of Lahovary's report were influenced by suggestions from Slovak officials. They would have wanted Romania to seek German protection and even its unconditional support. Economic policy would be the asset that Romania should use in gaining the sympathy of the Nazi Reich. ${ }^{12}$ It also meant that Bucharest should give up the alliance with England and France.

\section{Slovakia's international political status. Relations with the great powers}

The Treaty from March $23^{\text {th }} 1939$ regulated the German-Slovak relations and the international status of the small republic on the Danube. This document did not define Slovakia's independence but suggested it, leaving the Germans a significant influence on Slovakia's policy. Neither historians nor international law specialists have been able to explain the terms of the treaty, which preserve a number of ambiguities. A confidential memorandum specifies Slovakia's prerogatives but limits its sovereignty. The treaty can also be defined as an exercise by the Germans on how they could apply the rules of international law in the "New European Order", which they wanted to create. They used a series of tools to master their "clients", such as the army, intelligence services, various governmental agencies, but also the German minority in Slovakia. All these tools hide the idea of Slovakia's dependence on the Reich. Article $4^{\text {th }}$ of the German-Slovak Treaty stipulated that Slovakia's foreign policy was to be done only with the consent of Germany. Eventually, the German and Slovak leaders agreed to explain to the media and public opinion that this type of protectorate was not imposed on Slovakia but was a guarantee that Germany gave to the Slovaks. ${ }^{13}$

Lahovary made his own clarification regarding the international status of Slovakia. He showed that the internal autonomy was complete, the 1939 Protection Treaty demanding that only foreign affairs be in line with those of the Reich. These included some military provisions, such as the presence of the Wehrmacht units in the western bor-

\footnotetext{
12 A.M.F.A. Bucharest, fund 71 Slovakia, vol. 1, f. 111-114.

13 MIKUS, Joseph A.: La Slovaquie dans le drame de l'Europe (Histoire politique de 1918 a 1950). Paris : Les Iles d'Or, 1955, p. 160-161.
} 
der region of the country and the right of German troops to transit the country if needed. ${ }^{14}$

Slovak diplomacy had to organize very quickly. The lack of diplomacy personalities should not have been felt. The most experienced, such as Štefan Osuský or Vladimír Hurban, had been active in the structures of diplomacy of the former Czechoslovakia. And Ivan Milecz came from the Czechoslovak diplomacy as well. Ján Országh, Radúz Radlinský or Ladislav Szathmáry were consuls. Others, such as Karol Sidor, Matúš Černák and Jozef M. Kirschbaum, have been active in the domestic political life. Most came from other areas of public life. ${ }^{15}$ Being familiar with the proWestern experience and orientation of the Foreign Office staff in Bratislava, Germany has made some clarifications in the text of the treaty. Thus, the recognition of Berlin was necessary for the new posts or functions in the Slovak diplomatic corps. The Germans knew the diplomatic activity and orientation of the Slovak diplomats, so an agreement was needed for all the personalities who had a career in the former Czechoslovakia. These, coordinated by Ferdinand Ďurčanský, sought to bring Slovakia out of isolation and bring it closer to Western diplomatic circles and, last but not least, Soviet ones. This was how the Slovak leaders understood that Slovakia might have its own foreign policy.

That is why, for the Slovaks, recognition from England and France would be a success. The French representative, Milon de Peillon, has sent some reports to his government that heavily addressed the situation of Slovakia after independence. Speaking about the status of the country, he admitted that it was superior to the protectorate, considering it to resemble that of a British dominion. But he concluded that the presence of the German troops in the West of the country turned independence into a fiction. ${ }^{16}$ The Consuls of England and France, although their countries recognized de facto Slovakia's independence, left the country in September 1939 due to the participation of Slovakia in the campaign against Poland. The lack of unity in foreign policy can also be seen in the way some of Slovak diplomats acted. For example, Ladislav Szathmáry, Slovak minister in Warsaw, refused to return to Bratislava after September $1^{\text {st }} 1939$, taking a hostile attitude to the Slovak government. His debauchery would be an important piece of the Ďurčanský's file as Foreign Minister. ${ }^{17}$ Instead, on

\footnotetext{
${ }^{14}$ A.M.F.A. Bucharest, fund 71 Slovakia, vol. 1, f. 157.

15 PETRUF, Pavol: Zahraničná politika Slovenskej republiky (1939-1945), In: IVANIČKOVÁ, Edita a kol.: Slovenská republika 1939-1945 v medzinárodných súvislostiach. Bratislava : Historický ústav SAV, 2012, p. 18-19.

${ }^{16}$ KIRSCHBAUM, Stanislav J.: A History of Slovakia. The Struggle of Survival. New York : Palgrave Macmillan, 2005, p. 189.

17 DUURICA, Milan S.: The Foreign Policy of the Slovak Republic. Padova - Trieste : Edizioni Lint, 1984, p. 30.
} 
September $16^{\text {th }} 1939$, the Soviet Union recognized Slovakia's independence, breaking relations with the Czechoslovakian representatives in London. ${ }^{18}$ For Slovakia it was an important foreign victory because there were many voices which would have wanted a closer relation with the Soviet Union. In Bratislava, the establishment of diplomatic relations with U.R.S.S. was seen as a possible alternative against the German domination. Nicolae Lahovary noted that the Slovaks maintain a good relationship with Soviet diplomats, speaking of a great twinning. Instead, "although it cannot rely on Romania in the name of the Slavic solidarity which Slovakia is trying to use with Soviet Russia, it wants to strengthen our mutual relations, to that end, seeing Romania as a strong ally against the dangerous neighbour to the south [Hungary, our note]". ${ }^{19}$

During 1940, Slovakia tried to lead an independent policy, uncontrolled by the Third Reich. Slovakia did not declare war on France and the United Kingdom, trying to get in touch with the two countries through diplomats. Durčanský asked Ciano to pass this position to the British ambassador in Rome. He sent Fraňo Tiso, known as a philosopher and opponent of Germany, to the Soviet Union. ${ }^{20}$ There were even some contacts between Tiso, Ďurčanský and Beneš. The Hungarians approached Berlin accusing Slovakia of being too close to the Soviet Union. These accusations have raised Berlin's interest. Thus, Martin Bormann has prepared a plan to occupy the country and turning it into a protectorate similar to the Protectorate of Bohemia and Moravia. On March 13 $3^{\text {th }}$ 1940, Alfred Frauenfeld was sent to Bratislava with a special mission to draw up a report on the situation in Slovakia. This report spoke of the clericalism of the Slovaks that would have been closer to liberalism than national-socialism. The Jewish problem unresolved by the Slovaks was also reached. For now, Hitler made no decision as the military campaign against France was around the corner. The state of affairs in Central Europe also depended on the outcome of this confrontation. All these fluctuations were known to Lahovary.

\section{Slovakia's position regarding Hungary and its relations with Romania and Yugoslavia}

The Slovaks understood that for Romania the political-diplomatic relations with Czechoslovakia were of great significance. They sought to present Slovakia as an equally important and credible partner, despite the fact that it was a much smaller state and its foreign policy was dominated by Berlin. Thus, the Slovak government stated on May $10^{\text {th }} 1940$,

\footnotetext{
${ }^{18}$ MOLDOVEANU, Milica: Slovak Independent State. In: The fascist and totalitarian regimes in Europe, vol. III. Bucharest : Military Publishing House, 1979, p. 25.

${ }^{19}$ A.M.F.A. Bucharest, fund 71 Slovakia, vol. 1, f. 134-135.

${ }^{20}$ ĎURICA, Milan S.: op. cit., p. 21.
} 
on the occasion of a gala representation for Romania's National Day, that "it inherited its friendship with us", as a successor state of Czechoslovakia. The representation was opened by the speech of the Slovak Minister of Communications, Július Stano, who was the president of the RomanianSlovak Society. Jozef Tiso also attended the ceremony, signalling that the desire to maintain the relations between the two countries was manifested at the highest level. After the performance, Lahovary was invited to Hotel Carlton together with several political figures from the Slovak economic environment. On this occasion King Charles II of Romania was decorated with the highest Slovakian order, being the first Royal Head of State to receive the distinction. Minister Lahovary proposed that Romania also decorate a few Slovak representatives who showed pro-Romanian sympathies. ${ }^{21}$ The "Slovak”, in its May $17^{\text {th }}$ issue, wrote extensively about the audience of Minister Ivan Milecz to the King of Romania and the significance of the Pribina order, a decoration reserved only to the Heads of State. ${ }^{22}$

In the report dated on May $15^{\text {th }}$, the Romanian diplomat quoted a few paragraphs from the discussion with Ján Sivák, the Minister of National Education, to prove the Slovak interest for Romania to "remain strong”. Sivák's best solution was to tighten the Romanian-German relations on economic terms. He considered that Hungary speculated the Germans' discontent with Romania, and that the government in Bucharest ought to pay more attention to such discontents. Moreover, Minister Sivák continues: „The Slovak government would be happy if our relations with Soviet Russia could improve". And he continued by saying that although their influence in Moscow was small, the Slovaks would do their utmost to contribute to the Romanian-Soviet rapprochement. But Sivák was worried about the change in Moscow's foreign policy, which had become more aggressive „on the path of the imperialist pan-Slavic and expansive imperialist politics of the Czar", expressing its concern over the Bessarabian problem. From the discussion with the Minister of National Education, Lahovary understood that Slovakia's attitude was similar to that of Yugoslavia. ${ }^{23} \mathrm{He}$ was sure that the Slovak leaders wanted to maintain a good relationship with the two partners of the Little Entente, but not in the spirit in which this structure was created. Understanding that any

\footnotetext{
${ }^{21}$ A.M.F.A. Bucharest, fund 71 Slovakia, vol. 11, f. 130.

${ }^{22}$ Ibid., f. 136. In his Notes, the Romanian sovereign wrote that he was pleased of Milecz's visit and given decoration, but without making any other comment. It is known that King Carol II had no confidence in Slovakia, he would have just wanted Slovakia not to be incorporated into Hungary. King Carol II of Romania: Daily Notes, 1937-1951, volume III (December 15, 1939 - September 1940). Ed. by Nicolae Rauş. Bucharest : Scripta Publishing House, 1998, p. 171.

${ }^{23}$ A.M.F.A. Bucharest, fund 71 Slovakia, vol. 1, f. 134-135. 
The reflection of Slovak politics in 1940 in Nicolae Lahovary's ...

increase in Hungary's power would mean an equivalent increase of a threat to the Slovak state, Romania and Yugoslavia were placed on the same side. Since the revisionist intentions of Hungary were well known both in Belgrade and in Bucharest, the two countries would offer Slovakia the tranquillity it needed and two partners in the common struggle against Hungarian revisionism.

He made the same impressions following a discussion with Polyak, Undersecretary of State at the Slovak Foreign Ministry in May 1940. Lahovary noted the Slovaks' desire to have good relations with Yugoslavia. They preferred the Yugoslav state to remain neutral in war to be attracted, alongside the Romanian-Slovak rapprochement, into a common anti-Hungarian policy. Moreover, Polyak expressed the hope that the Romanian-Soviet relations could relax and openly show support for this expansion by direct diplomatic initiatives in Moscow. ${ }^{24}$ Slovak diplomats understood that the Soviet pressures against Romania, doubled by the German ones in Belgrade, were jeopardizing their interests. In Bratislava, the only enemy was Hungary, and a weakening of Romania or Yugoslavia was a danger to the Slovak interests. Instead, the three countries that surrounded Hungary were a guarantee for Slovakia's survival even without Berlin's insurance. It is hard to say how much the Slovak diplomacy was able to impose its influence on both Belgrade and Bucharest. Following the talks with Polyak, Lahovary understood his concern about the Italian-Hungarian rapprochement. He believed that Romania and Slovakia should pursue a common policy in Rome. But the Slovak politician considered that the Hungarians did not have much credit in Berlin, which would facilitate the Romanian-Slovak rapprochement. ${ }^{25}$

The Romanian minister suggested in his report sent back to the country that the Slovak state authorities were not mere emanations of the German government. Lahovary compares them with the Romanians in Transylvania during the Austro-Hungarian national movements: "The Slovaks were more similar to the Czechs, than they were to the Romanians in Transylvania." He concludes that the differences "between the Czechs and the Slovaks were more clear-cut than the blurred out distinctions between Transylvanians and Regateans ${ }^{* \prime} .{ }^{26}$ The call to a common past made it clear that the Romanians in Transylvania and the Slovaks had a common enemy, and that the relations between Romania and Slovakia could be articulated precisely against it, without the necessity for them to be

\footnotetext{
${ }^{24}$ Ibid, vol. 11, f. 143

${ }^{25}$ Ibid, vol. 1, f. 168-169.

${ }^{*}$ By the inter-war Romania regatean it was understood the Romanians from the Old Kingdom before 1918.

${ }^{26}$ Ibid, vol. 11, f. 130-32.
} 
made public. The integration of the Slovaks in the Czechoslovak state was perceived as artificial and completely different from the unity of the Romanians in Transylvania and those in the Old Kingdom. Those were the first steps in establishing ties with the Slovaks, which had to prove in Romania that the relations between the two countries could be established on durable bases, with a long history. The public opinion in Romania knew relatively little about the Slovak nation, and Lahovary's suggestions were to open a series of mutual contacts.

Two days later, on June $17^{\text {th }}$, Lahovary handed over to Bucharest a new report in which he shed a light on what he had stated earlier about the Slovak state being a German creation. He believed that Berlin did not occupy Slovakia, since it did not want to upset the Italians, who supported the Hungarian claims, nor the Russians, because "the sympathy between Slovaks and Russians is well known". He said that there were many voices in Slovakia who wanted a rapprochement with the Soviet Union as a guarantee of the state existence, as Germany would no longer be able to support the Slovak state. Some went so far as to prefer the country to be occupied by the Russians "rather than relive the Hungarian oppression" 27. For the time being, however, Germany was against too much proximity between Slovakia and the Soviet Union.

\section{Internal political situation}

The Romanian diplomat was also concerned with the domestic situation of Slovakia. Lahovary appreciated the national and Christian character of the Slovak Constitution, which was due to the ideology of Hlinka's party. He added that "the Christian idea that derives and is further propagated from the Constitution is viewed favorably by the Germans, who, being aware of the religiousness of the Slovak people, see this as yet another obstacle in the path of communist propaganda"28. Lahovary's report from June $17^{\text {th }}$ details the system of the Slovak political life, Hlinka's Slovak People's Party and Hlinka Guard, so he concludes that "the political organization of Slovakia is formed on a mixed regime: parliamentary and totalitarian". It was this mix that caused the political crisis, the radical tendencies of the Hlinka Guard, colliding with the followers of a more moderate form of dictatorship. For Lahovary it was clear that the Slovak political system "gives people the impression of being in charge" and "prevents the government from drafting decrees that would be in contradiction with party spirit and guidelines". Lahovary gave importance to the status of minorities in Slovakia. Although there was no Romanian community

\footnotetext{
${ }^{27}$ Ibid., vol. 1, f. 154-155.

${ }^{28}$ Ibid, f. 157. 
The reflection of Slovak politics in 1940 in Nicolae Lahovary's ...

in Slovakia, he drew special attention to the status of the Germans, who enjoyed rights over constitutional regulations. ${ }^{29}$

Another report sent by Lahovary in June 1940 was about the internal political situation in Slovakia. Alexander Mach's resignation from Hlinka Guard triggered a ministerial crisis that the Slovak authorities failed to hide. Although Ferdinand Durčanský denied that there was a conflict at the top of Slovakia's leadership, the absence of German diplomat Hans Bernard for more than two weeks in the country drew the attention of the Diplomatic Corps. Even though they had been invited, the German journalists didn't attend the Foreign Minister's press conference, which led to an amplification of the rumours about the struggle at the top of the Slovak power, between the pro-German side and that of Ferdinand Durčanský. Apparently, Mach had certain ambitions about the posts in the Slovak government, and accused the Foreign Minister of being a 'pro forma' anti-Semite and of accepting benefits from the Jewish economic environments. He was even accused of his attitude to Germany not being honest.

Lahovary correctly guessed that there was a political power dispute in Slovakia between the moderate representatives, who wanted to implement their political program gradually - with the regard to the evolution of the events - and the radicals of Tuka and Mach, who went alongside Germany unconditionally. The situation was complicated by the fact that Franz Karmasin, the leader of the German Party in Slovakia, encouraged Mach by promising him the Reich's support. Although the German community in Slovakia was not very numerous, it had an important support in Bratislava. Any protest of the Hlinka Guard might receive the support of the German National Socialists in the capital and would hinder the position of the government. As the Hlinka Guard enjoyed an important support in the country's capital, Ferdinand Ďurčanský refused to take tough action. He preferred to seek support in the certain Slovak regions by undertaking a tour in the north of the country to support his point of view and respond to the accusations they brought to him. In this dispute, the Jewish community became a victim, as the measures taken by Ferdinand Durčanský to prove his anti-Semitic policy affected the Jews. In turn, the Czechs were also victims of this conflict. Ferdinand Ďurčanský denied the accusation of "moderation" towards the Czechs, eliminating them from state structures or expelling them across the border. Duurčanský wanted to prove his anti-Semitic policy, showing that „while others talk, he acts". He also stated that 9,000 Czechs who had functioned in the state apparatus had been "dismissed and sent across the border". Another 2,000 were to be evicted to the Protectorate in a maxi-

${ }^{29}$ Ibid., f. 168. 
mum of one month. Lahovary did not take a stand on the outcome of this political crisis, because he did not know what the position of Germany would be. ${ }^{30}$ The French offensive did not allow Berlin to deal with the Slovak crisis as a priority, which led to its delay. Lahovary believed that Durčansky was an „energetic and positive spirit”, but he considered that Tuka "though having a wider and less provincial culture, is more of a theoretician and a dreamer, a little too cautious". ${ }^{31}$

The fate of the regime in Slovakia was decided by Germany's victory in France. Soon, Hitler made the decision to impose the Treaty of Protection the way he chose to interpret it. On July 27, he invited the Slovak leaders to consultations in the Austrian city of Salzburg. The meeting of July $27^{\text {th }}-28^{\text {th }} 1940$ between Hitler and Tiso, Tuka and Mach represented the end of Durčanský's ambitions to pursue his own foreign policy. Von Ribbentrop criticized Slovakia's brutal policy and Hitler had a long monologue in which he presented his point of view. The meeting led to the replacement of Durčanský with Tuka in the Ministry of the Foreign Affairs, and this was a drastic intervention in the internal politics of the country. The appointment of the radicals Tuka and Mach, approved by Berlin, meant changing the country's political orientation. On this occasion, Ribbentrop told Tuka about the need to appoint German advisors to the Ministries of the Internal Affairs, Propaganda, Economics, and in dealing with the Hlinka Guard and the Jewish problem. They were considered experts in various issues who had to make their contribution to the implementation of the "new order" in the European countries. ${ }^{32}$

The obtention of numerous positions and functions within the state by the representatives of the Hlinka Guard was another German brutal intervention in the internal politics of Slovakia. Then the appointment of Manfred von Killinger as the diplomatic representative of the Reich in Slovakia was not just a change of diplomats. Killinger had the task of imposing German claims on Bratislava. Moreover, it has been suggested on various occasions that after the meeting in Salzburg the position of the Slovak Republic became a similar to the Protectorate of Bohemia and Moravia. ${ }^{33}$ Documents issued by the Romanian Legation made this change visible. The Salzburg meeting between Adolf Hitler and the Slovak delegation was further evidence of the "synchronization between the

\footnotetext{
${ }^{30}$ Ibid., f. 144-147.

${ }^{31}$ Ibid., f. 174.

${ }^{32}$ HRADSKÁ, Katarína: The Influence of German on the "Solution of the Jewish Question" in Slovakia. In: DŁUGOBORSKI, Wacław and others: The Tragedy of the Jews of Slovakia, 19381945: Slovakia and the „Final Solution of the Jewish Question”, Oświęcim - Banská Bystrica : Auschwitz-Birkenau State Museum - Museum of the Slovak National Uprising, 2002, p. 89. ${ }^{33}$ ĎURICA, Milan S.: op. cit., p. 24-25.
} 
The reflection of Slovak politics in 1940 in Nicolae Lahovary's ...

political regimes of the two countries". In fact, by approaching the Reich, Slovakia has integrated itself into the German sphere of interests, giving up a series of prerogatives of being an independent state. The fact that this process was delayed by the leaders in Bratislava was due to their tendencies to preserve the appearance of an independent state. The Slovak delegates motivated the delay with the argument that between 1939 and 1940 it was necessary to remove from the structures of the new state all those who „suffered from a Czechoslovak sentimental inertia” 34 .

\section{The Romanian crisis and its echo in Slovakia}

Romania was going through a much deeper crisis at that time to pay close attention to Slovakia's problems. This important moment in Romania's drama held Lahovary in Bratislava. The position of the Slovaks towards the Bessarabia and Bukovina issue was taken in his analysis. In a visit he made to Lahovary, Minister Stano showed his compassion for the drama suffered by Romania. He expressed his conviction that Germany did not make an understanding with the Soviet Union about Bessarabia and Bukovina. He was of the opinion that Berlin could not approve the Soviet expansionist policy towards Central Europe and that it could lead to a war between the two. He also believed that U.R.S.S. will also claim Ruthenia, which will force Germany to support Hungary. At the same time, he believes that Soviet successes will not strengthen Slovakia's proBolshevik feelings and that it will remain faithful to pro-German orientation. ${ }^{35}$ And Ferdinand Ďurčanský called Lahovary to ensure that Slovakia was on the side of Romania and that he could rely on any advice. ${ }^{36}$

The Slovaks were not as honest about the Transylvanian issue. The politicians in Bratislava paid interest in the Romanian-Hungarian negotiations and hoped that the signing of a bilateral agreement could provide a model for the settlement of the situation of Hungarians living in the country. ${ }^{37}$ The circles around the Hlinka Guard believed that Romania would share the fate of Czechoslovakia and that it was better for Slovakia because a new amputation of Romania would throw it in the hands of Germany. ${ }^{38}$ The proximity of Germany will force Romania to find its way to Bratislava in its desire to face other Hungarian claims. On the other hand, the moderates around Durčanský were anxious in realizing that any territorial enlargement of Hungary would represent an

\footnotetext{
${ }^{34}$ Service of Central National Historical Archives, Bucharest. Fund Ministry of National Propaganda. External press, d. 1120, f. 5 (infra: S.C.N.H.A.).

${ }^{35}$ A.M.A.E. Bucharest, fund 71 Slovakia, vol. 11, f. 161-162.

${ }^{36}$ BAUEROVÁ, Jana: op. cit., p. 38.

${ }^{37}$ S.C.N.H.A. Bucharest, fund Ministry of National Propaganda. External press, d. 1120, f. 5.

${ }^{38}$ A.M.F.A. Bucharest, fund 71 Slovakia, vol. 11, f. 164.
} 
increase in its political-military capacity. They would have wanted a strong attitude of Romania, convinced that the Hungarians did not have support in Berlin. ${ }^{39}$

The Slovaks hoped that an ethnic rectification in Transylvania could lead to one between Slovakia and Hungary on the same coordinates. They supported the Romanian point of view and solved the ethnic problem with the exchange of the population. ${ }^{40}$ Lahovary was concerned about the fact that the Slovaks were asking for a status in Hungary similar to that of the Hungarians in Slovakia. This status was imposed by Germans who had an important minority and could have repercussions in Transylvania. Lahovary was more willing to accept the current situation because it would be „a very strong argument against the Hungarian revisionist theses". ${ }^{41}$ The conviction of the Romanian press attaché, Moise Baltă, was that „the Hungarian governors treat the Slovaks with an arrogance of world power". ${ }^{42}$ „Slovák”, the central press of the regime, has permanently informed the public about the negotiations between the Romanians and the Hungarians, creating a certain state of mind that would favour a possible Slovak revocation of the border. When the negotiations were blocked, Hungary mobilized the reservists and prepared to cross the border against Romania. Milecz reports that the war between the two is sure. ${ }^{43}$

In July 1940, in the context of the Romanian-Hungarian negotiations, Lahovary came to Bucharest to discuss with Romanian Foreign Minister Manoilescu about the details of the Romanian-Slovak cooperation. Now he had the opportunity to meet Ivan Milecz. Lahovary told his counterpart that his stay in Slovakia was enough to convince him of Slovaks' sympathy for Romania. ${ }^{44}$ Returned to Bratislava in August 1940, Lahovary met the newly-appointed head of German diplomacy in Bratislava, Manfred von Killinger. The German diplomat said the Reich wanted an approach with Romania. He explained to Lahovary that Romania would not have missed Bessarabia if, immediately after Poland's defeat, Bucharest had allied with Berlin. The settlement of the Soviet Union at the entering sides of the Danube was „in the first place disliked” by Germany. But Killinger suggested to the Romanian minister that once Romania's territorial problems were resolved, it would have no reason to fear the Soviet Union. Killinger notified Lahovary ten days

\footnotetext{
${ }^{39}$ Ibid., f. 172.

${ }^{40}$ Ibid., f. 169.

${ }^{41}$ Ibid., f. 147-148.

${ }^{42}$ S.C.N.H.A. Bucharest, fund Ministry of National Propaganda, Internal press, d. 1170, f. 107.

${ }^{43}$ BAUEROVÁ, Jana: op. cit., p. 75.

${ }^{44}$ Eabidem, p. 38.
} 
The reflection of Slovak politics in 1940 in Nicolae Lahovary's ...

before the Vienna Agreement that Germany could guarantee in the future all of Romania's borders. ${ }^{45}$

The second Vienna agreement followed, whereby Transylvania was divided between Hungary and Romania. Nicolae Lahovary and Moise Baltă participated alongside their colleagues from the capitals of the states involved, claiming the Romanian delegation but not receiving them at the Belvedere Palace. ${ }^{46}$ The decision made in Vienna offended the public opinion in Slovakia which was hoping to receive some compensation. Instead, the strengthening of Hungary was perceived as a potential increased threat to them. The Slovaks again relied on the hope that the satisfaction of the Hungarian claims that brought them a large territory from Transylvania would temper the Hungarians who would be willing to renegotiate a rectification of the Slovak-Hungarian border. ${ }^{47}$ The Romanian diplomat in Bratislava has suggested to the Slovaks to demand that the rectification that might occur should be made at a conference from which Romania could not miss. ${ }^{48}$ The press talked about the price that Romania had to pay to get the security guarantees in the New Europe. ${ }^{49}$ The "Grenzbote”, the newspaper of the German community in Slovakia, influenced by Berlin, concluded that the former king of Romania „became the political instrument of the Western Powers, especially of England". ${ }^{50}$ Instead, the official "Slovak" publishes an article condemning the Vienna Agreements that allowed the enlargement of Hungary's territory on behalf of Slovakia and Romania. ${ }^{51}$

The political transformations that took place in Romania in September brought Slovakia closer to Romania. The mission of Nicolae Lahovary did not end with the change of the Bucharest regime in September 1940. But in the new context his activity was rethought and put on other bases. The proximity of Germany and the guarantees granted to Romania led to a tightening of the bilateral ties between Bratislava and Bucharest.

\section{Conclusions}

The international status of the newly created Slovak Republic was defined by the German-Slovak Treaty of Protection signed on March 1939. The ambiguities of this document - which gave Germany the opportunity to interpret it - and the danger of influencing the policy pur-

\footnotetext{
${ }^{45}$ LUNGU, Corneliu Mihail - NEGREANU, Iona Alexandra: op. cit., doc. 117, p. 352.

${ }^{46}$ BOSSY, Raoul: Memories of Diplomatic Life (1918-1940), volume II, 1938-1940. Ed. by Stelian Neagoe. Bucharest : Humanitas Publishing House, 1993, p. 279.

${ }^{47}$ A.M.F.A. Bucharest, fund 71 Slovakia, vol. 11, f. 173.

${ }^{48}$ Ibid., f. 174.

${ }^{49}$ BAUEROVÁ, Jana: op. cit., p. 74.

${ }^{50}$ S.C.N.H.A. Bucharest, fund Ministry of National Propaganda. External press, d. 1170, f. 90.

51 Ibid., f. 98.
} 
sued in Bratislava, diminished the confidence of Romanian authorities in the Slovak state. However, after the development of political events in winter of 1939 - 1940, Slovakia became increasingly interesting for Romanian diplomacy. It could be treated as an ally against Hungary, but also as a transmission belt in relation to Berlin. In the political balance of the Bucharest regime in the first half of 1940, the mission of Nicolae Lahovary played a significant role. His reports focused on a wide range of issues, aiming to lay the foundations for a future Romanian-Slovak collaboration. This required a clear definition of the Slovakia's dependence on Germany.

The central objective of the Slovak diplomacy was to defend itself against Hungarian aggression. Hungary would have wanted the entire Slovak state to be incorporated into its frontiers. As these intentions were well known in Bratislava, the dependence on Berlin assured the Slovak statehood. Romania had to define its interests towards Slovakia according to this reality. Therefore, it declared of its support for Slovakia's integrity, but did not get too close to it, as long as the AngloFrench guarantees could still ensure its own integrity. Instead, the collaboration intensified in areas where the common interest was evident. The Hungarian danger played a decisive role in the Romanian-Slovakian rapprochement. Lavohary always informed Bucharest about the feelings of the Slovaks towards the Hungarians, and their desire to cooperate with Romania and Yugoslavia against this peril. In order to give consistency to the Romanian-Slovak relations, a good knowledge of the Slovak political class and of the internal political system was needed. Lahovary had also done his duty in this regard by reporting in detail the domestic political crisis in Slovakia and defining the two sides. But it was not the common interests and the better knowledge of the Slovak society by Romanian diplomacy that led to the rapprochement between the two countries. The suspicion with which Slovakia was regarded in Bucharest before the summer of 1940 was mutual in Bratislava. This fact was also demonstrated by the attitude of the Slovaks during the Transylvanian crisis. The lack of unity in Slovakia's internal politics was "solved" by the Germans through an arbitrary act. Lahovary captured Bratislava's reluctance. The Romanian-Slovak rapprochement did not take into account the wishes of the two nations, but the political developments of 1940 . The collapse of Greater Romania and the change in the political orientation of Bucharest in September 1940 made possible a closer cooperation between the two countries. 
The reflection of Slovak politics in 1940 in Nicolae Lahovary's ...

\section{Zhrnutie}

\section{Reflexia slovenskej politiky v roku 1940 v diplomatických sprá- vach Nicolae Lahovaryho}

Nicolae Eric Lahovary bol rumunský diplomat, patriaci do starej rodiny, ktorá dala Rumunsku viacero politikov a diplomatov. V medzivojnovom období a počas druhej svetovej vojny absolvoval niekol'ko diplomatických misií. Medzi jeho najúspešnejšie misie patrilo pôsobenie na Slovensku, ktoré sa osamostatnilo v marci 1939 po rozpade Československa. Naša štúdia analyzuje jeho diplomatickú činnost' v hlavnom meste Slovenska. Za vel'vyslanca bol menovaný v marci 1940 a stal sa tak posledným rumunským diplomatom počas režimu král'a Karola II., ktorý bol vyslaný do jedného z partnerských štátov nacistickej ríše. Hoci bol vel'vyslancom až do marca 1941, v štúdii analyzujeme len prvý polrok jeho pôsobenia, teda od marca do septembra 1940. Zameriavame sa najmä na jeho vnímanie vnútornej a zahraničnej politiky Slovenskej republiky a tiež na podobu vzt'ahov medzi Slovenskom a Rumunskom. Po zmene politického režimu v Bukurešti bola Lahovaryho činnost’ ovplyvnená novou zahraničnopolitickou orientáciou krajiny.

Z jeho správ nás prekvapila pozícia Slovenska v medzinárodnom politickom systéme a snaha jeho vlády o upevnenie čo najnezávislejšieho postavenia voči Berlínu. Vzt’ahy s Rumunskom boli silne ovplyvnené celkovou situáciou v Európe v prvých mesiacoch roku 1940. Lahovary hodnotil aj vzájomné vzt'ahy medzi Rumunskom, Slovenskom a Mad'arskom, ktoré boli výrazne poznačené nepriatel'stvom a otvorenými konfliktmi. Tie tvorili základ pre vzájomné zblíženie medzi Bratislavou a Bukurešt'ou. V jeho správach boli zohl'adnené aj špeciálne vzt'ahy, ktoré slovenská diplomacia budovala so Sovietskym zväzom, a oscilácie vzt’ahov s Nemeckom, ktoré z toho vyplynuli.

V samostatnej časti textu štúdie sme upozornili na Lahovaryho správy, ktoré hodnotili vnútropolitickú situáciu Slovenska. Pozornosti rumunského diplomata neušiel ani konflikt medzi mocenskou skupinou okolo prezidenta Jozefa Tisu a predstavitel'mi Hlinkovej gardy, v ktorej dominoval Alexander Mach. Lahovarymu tento konflikt pripomínal konflikt medzi Legionárskym hnutím a rumunskou vládou, ktorý na konci tretieho desat'ročia definoval rumunskú vnútornú politiku. $V$ záverečnej časti štúdie sme analyzovali rozpory v rumunsko-slovenských vzt'ahoch, ktoré boli zapríčinené rozpadom Vel'kého Rumunska, a na ktoré v diplomatických správach upozornil samotný Lahovary. Zmena politického režimu v Bukurešti v septembri 1940 a preorientovanie sa rumunskej zahraničnej politiky prinútili Lahovaryho zmenit' niektoré stanoviská a ciele jeho pôsobenia. Napokon bol v marci 1941 z pozície vel'vyslanca odvolaný a nahradený Gheorghe Elefterescom. 